\title{
Determination of Multiple Antioxidant Activities of Endemic Tricholoma anatolicum H.H Doğan \& Intini Collected from Turkey
}

\author{
Hatıra Taşkın', Tülin Eker², Fuat Bozok ${ }^{3 *}$, Hasan Hüseyin Doğan ${ }^{4}$, Saadet Büyükalaca1 \\ ${ }^{1}$ Department of Horticulture, Faculty of Agriculture, Çukurova University, 01330 Adana, Turkey \\ ${ }^{2}$ Department of Food Engineering, Faculty of Engineering, Osmaniye Korkut Ata University, 80000 Osmaniye, Turkey \\ ${ }^{3}$ Department of Biology, Faculty of Arts and Science, Osmaniye Korkut Ata University, 80000 Osmaniye, Turkey \\ ${ }^{4}$ Department of Biology, Faculty of Science, Selçuk University, 42030 Konya, Turkey
}

\section{A R T I C LE INFO}

\section{Research Articles}

Received 29 May 2018

Accepted 18 September 2018

Keywords:

Tricholoma anatolicum

Antioxidant

DPPH

NO

FRAP

"Corresponding Author: E-mail: fuatbozok38@gmail.com

\section{A B S T R A C T}

Tricholoma anatolicum H.H. Doğan \& Intini is known as the most prized mushroom species in Feke region of Turkey. This mushroom species is collected from Cedar (Cedrus libani) forests and therefore is named as Cedar mushroom in this region. It is collected and consumed by local collectors and also exported to Far East countries such as Japan by exporting companies. Therefore, it is important to investigate the nutritional and medical importance of this species. The aim of this study is to reveal the antioxidant activity of methanol extract in different concentrations $(1,2$ and $4 \mathrm{mg} / \mathrm{mL})$ of $T$. anatolicum H.H. Doğan \& Intini collected from Feke district of Adana province of Turkey in 2015. In this study, it was determined that total phenolic content of this mushroom was $56 \mathrm{mg} / \mathrm{kg}$. 2,2-diphenyl-1-picrylhydrazyl (DPPH), nitric oxide (NO) and reducing power $(\mathrm{RP})$ activities given in trolox $(\mu \mathrm{M})$ and ferric-reducing antioxidant power (FRAP) given in $\mathrm{FeSO}_{4}(\mu \mathrm{M})$ were found as 449, 180, 337 and 2 at the highest concentration $(4 \mathrm{mg} / \mathrm{mL})$, respectively. As a result, it could be suggested that methanol extract of T. anatolicum H.H. Doğan \& Intini has significantly antioxidant activity.

Türk Tarım - Gıda Bilim ve Teknoloji Dergisi, 6(11): 1582-1585, 2018

\section{Türkiye'den Toplanan Endemik Tricholoma anatolicum'un Çoklu Antioksidant Aktivitesinin Belirlenmesi}

M A K A L E B İ L G İ S İ

\section{Araştırma Makalesi}

Geliş 29 Mayıs 2018

Kabul 18 Eylül 2018

\section{Anahtar Kelimeler:}

Tricholoma anatolicum

Antioksidan

$\mathrm{DPPH}$

NO

FRAP

"Sorumlu Yazar:

E-mail: fuatbozok38@gmail.com
Ö Z

Tricholoma anatolicum H.H. Doğan \& Intini Adana'nın Feke ilçesinde en değerli mantar türü olarak bilinmektedir. $\mathrm{Bu}$ mantar türü Sedir (Cedrus libani) ormanlarından toplanmaktadır ve bu nedenle bu bölgede sedir mantarı olarak adlandırılmaktadır. Bölgede lokal halk tarafindan toplanarak tüketilmekte ve aynı zamanda Japonya gibi Uzak Doğu ülkelerine ihracat firmaları tarafından ihraç edilmektedir. Bu nedenle, bu türün besleyici ve tıbbi özelliklerini araştırmak önemlidir. Bu çalışmanın amacı, 2015 yılında Adana ilinin Feke ilçesinden toplanan $T$. anatolicum türünün farklı konsantrasyonlarda $(1,2$ ve $4 \mathrm{mg} / \mathrm{mL})$ metanol ekstraktının antioksidan aktivitesini ortaya çıkarmaktır. Çalışma sonunda, bu mantarın toplam fenolik içeriği $56 \mathrm{mg} / \mathrm{kg}$ olarak tespit edilmiştir. Trolox'da verilen $(\mu \mathrm{M})$ 2,2-difenil-1-pikrilhidrazil (DPPH), nitric oxide (NO) ve indirgeme gücü (RP) aktiviteleri ve $\mathrm{FeSO}_{4}(\mu \mathrm{M})$ 'de verilen ferrik indirgeyici antioksidan (FRAP); en yüksek konsantrasyonda (4 mg/mL) sirasiyla 449, 180, 337 ve 2 olarak bulunmuştur. Sonuç olarak, T. anatolicum'un metanol ekstraktının önemli ölçüde antioksidan aktiviteye sahip olduğu söylenebilir. 


\section{Introduction}

Genus Tricholoma which are included many species such as Tricholoma anatolicum H.H. Doğan \& Intini, T. matsutake (S. Ito \& S. Imai) Singer and T. magnivelare (Peck) Redhead have an importance because of their edible, medicinal and commercial specialties. Especially, T. matsutake (S. Ito \& S. Imai) Singer is often consumed by local people in Japan due to its taste, aroma and medicinal properties (Taşkın and Büyükalaca, 2016). T. anatolicum H.H. Doğan \& Intini is also known as the most prized edible mushroom species in Feke district of Adana province of Turkey. This species is endemic to Turkey and found in Adana, Antalya, Kahramanmaraş, Karaman, Konya and Osmaniye throughout Mediterranean region (Taurus Mountains) of Turkey (Doğan and Akata, 2011). This species which collected from Cedar (Cedrus libani) forests is named as Cedar mushroom in this region. T. anatolicum H.H. Doğan \& Intini is collected and consumed by local collectors and also exported to Far East countries such as Japan by export trading companies. Therefore, it is important to investigate the nutritional and medical importance of this species.

Previous studies have focused on the chemical composition and nutritional quality of different species of the genus Tricholoma in Turkey (Kalmış et al., 2011; Doğan et al., 2012; Özdemir, 2014; Özkaya, 2015; Akgül et al., 2016). It is also important to know antioxidant properties of $T$. anatolicum H.H. Doğan \& Intini. Our objective was to evaluate the total phenolic content and antioxidant properties including different antioxidant assays of T. anatolicum H.H. Doğan \& Intini.

\section{Material and Methods}

T. anatolicum H.H. Doğan \& Intini were collected under Cedar trees from Adana (Feke) province of Turkey in September 2015 (Fig 1) and dried at $50^{\circ} \mathrm{C}$ in a dehydrator during $24 \mathrm{~h}$. Dried mushroom samples were powdered in blender. The extraction of the samples powdered $(50 \mathrm{~g})$ was performed during $72 \mathrm{~h}$ at $60^{\circ} \mathrm{C}$ in $500 \mathrm{~mL}$ of methanol $(\mathrm{MeOH})$, then filtered, and also the methanol was evaporated. Extract was kept in refrigerator until the analysis at $+4^{\circ} \mathrm{C}$. Samples collected have been deposited at Department of Biology, Osmaniye Korkut Ata University.

Total phenolic content of T. anatolicum H.H. Doğan $\&$ Intini was monitored by the Folin-Ciocalteu reagent (Gürsoy et al., 2009). Different concentrations (1, 2 and 4 $\mathrm{mg} / \mathrm{mL}$ ) of methanol extract were used to determine the antioxidant activity with varied assays. 2,2-diphenyl-1picrylhydrazyl (DPPH) scavenging activity (BrandWilliams et al., 1995), nitric oxide (NO) scavenging activity (Garrat, (1964), ferric reducing ability antioxidant power (FRAP) estimation (Benzie and Strain 1996) and reducing power activity (RP) (Oyaizu 1986) of methanol solution were measured.

The experimental data was evaluated by using analysis of variance (ANOVA, Tukey) with SPSS 18 programme (Chicago, IL, USA).

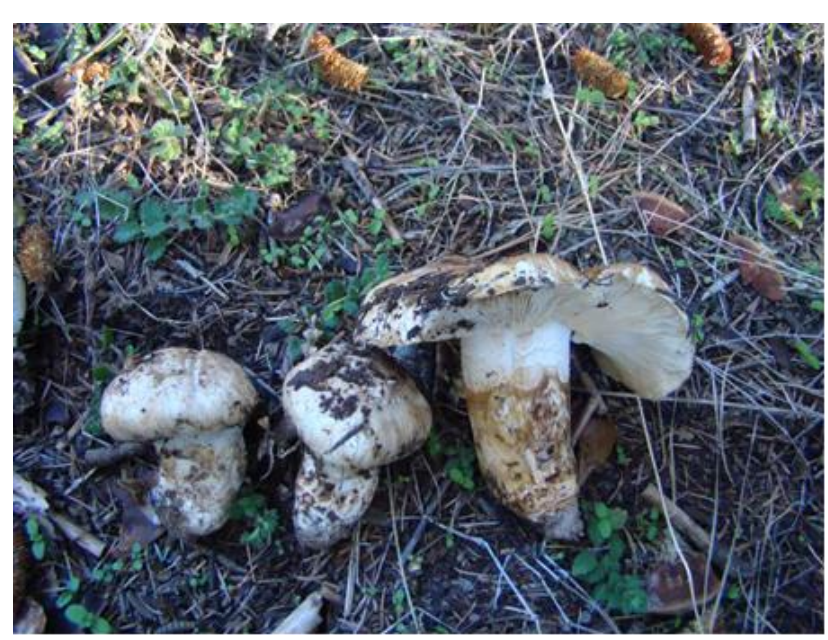

Figure 1 Basidiomata of Tricholoma anatolicum collected from Feke-Adana (Turkey)

\section{Results and Discussion}

Phenolic compounds, which generally found in most plants, contribute to coloration and sensory properties (Rice-Evans et al., 1997). These compounds inhibited the oxidation of in vitro low density lipoprotein (LDL) and development of tumors by neutralizing free radicals (Stacewicz-Sapuntzakis et al., 2001). In the present study, total phenolic content of T. anatolicum H.H. Doğan \& Intini is found as $56 \mathrm{mg} / \mathrm{kg}$. When compared with previous studies (Yang et al., 2002; Elmastas et al., 2007; Gürsoy et al., 2009; Bozok et al., 2016; Bozdoğan et al., 2016), this amount is moderate (Table 1 ).

Table 1 Total phenolic content of Tricholoma anatolicum and comparison with other mushroom species in the literature

\begin{tabular}{l|r}
\hline \multicolumn{1}{c|}{ Species } & \multicolumn{1}{|c}{ TPC } \\
\hline Agaricus bisporus (Elmastas et al., 2007) & 13.10 \\
Ganoderma lucidum (Bozok et al., 2016) & 114.55 \\
Morchella conica (Gürsoy et al., 2009) & 25.38 \\
Pleurotus ostreatus (Yang et al., 2002) & 15.70 \\
Ramaria flava (Bozdoğan et al., 2016) & 89.00 \\
Tricholoma anatolicum (in this study) & 56.00 \\
\hline
\end{tabular}

TPC: Total Phenolic Content (mg/kg)

Multiple antioxidant activities of this mushroom increased significantly in different assays (DPPH, NO, FRAP and RP) depending on the concentration increase. DPPH, NO scavenging activities and RP of different concentrations $(1,2$ and $4 \mathrm{mg} / \mathrm{mL})$ were found as 273 , 304, 449 and 14, 43, 180 and 122, 218, 337 given in trolox equvalent $(\mu \mathrm{M})$, respectively (Fig 2). DPPH scavenging assay was the most common methods for determining in vitro antioxidant capacity of materials (Elmastas et al., 2007). Furthermore, the use of DPPH radical has the advantage that it is not affected by side reactions such as enzyme inhibition and metal chelation (Wettasinghe and Shahidi, 1999). NO is a labile molecule produced in mammalian cells. 

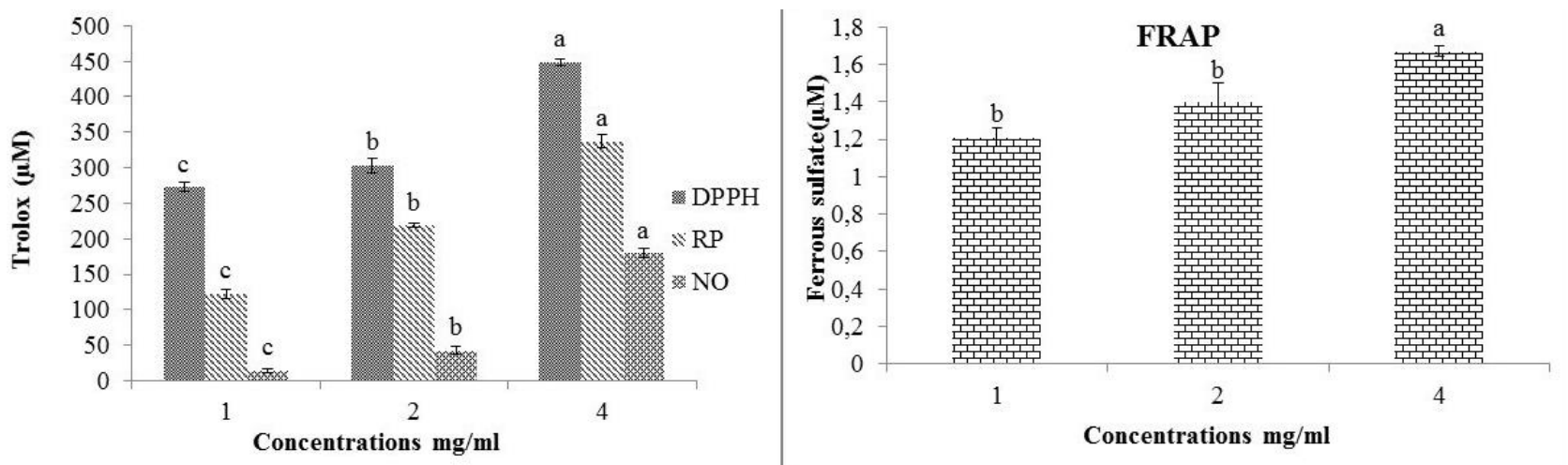

Figure 2 Antioxidant activities of Tricholoma anatolicum' methanol extract (Data were analyzed by using SPSS statistics software version 17.0 (SPSS Inc., Chicago, IL, USA) and Tukey-HSD test was used for determining the separation of means at $\mathrm{P}>0.05$ )

Apart from its role in physiological process, NO also has a toxic property, especially after reaction with oxygen or superoxide anion radicals (Vriesman et al., 1997). FRAP capacity $(\mu \mathrm{M})$ of $T$. anatolicum H.H. Doğan \& Intini methanol extract at 1,2 and $4 \mathrm{mg} / \mathrm{mL}$ concentrations was $1.20,1.40$ and 1.67 , respectively. FRAP assay is widely used to quickly assess the total antioxidant capacities of various materials (Benzie and Szeto, 1999; Moyer et al., 2002; Wong et al., 2006). It could not be compared with antioxidant capacities of other macrofungal species, because results which obtained from this study on antioxidant capacity of $T$. anatolicum H.H. Doğan \& Intini are different in terms of unit.

Antioxidant activity results derived by using multiple assays are in a wide range. The highest values were obtained in DPPH assay in all concentrations, while the lowest values were measured in FRAP assay. A number of reasons may be taken into account to clarify the different obtained results between the assays such as the reaction mechanisms, reaction media, $\mathrm{pH}$, the chemical properties of active compounds presented in the extracts, their interactions and other factors (Smolskaite et al., 2015).

Oxidation is important for many living organisms to produce energy (Halliwell and Gutteridge, 1984). It was reported that free radicals and other reactive oxygen types produced in cells cause some diseases such as cancer, diabetes, cirrhosis and rheumatism (Halliwell and Gutteridge 1984; Chan et al., 1997; Visioli et al., 2000; Barros et al., 2007). It has been indicated that consumption of foods having natural antioxidants might be helpful to human body for reducing oxidative damage (Nakayama et al., 1993; Halliwell, 1996; Elmastas et al., 2007).

Results obtained from this study show that methanol extract of $T$. anatolicum H.H. Doğan \& Intini has significantly antioxidant activity. In further researches, antioxidant capacities of different extracts such as ethanol, water, acetone of this mushroom species can be investigated. However, it could be suggested for isolation and identification of compounds which responsible for the antioxidant activity in T. anatolicum H.H. Doğan \& Intini.

\section{Acknowledgements}

The authors would like to thanks to Çukurova University Research Funding (Project no ZF2013D10) for supporting this study.

\section{References}

Akgül H, Nur AD, Sevindik M, Doğan M. 2016. Tricholoma terreum ve Coprinus micaceus'un bazı biyolojik aktivitelerinin belirlenmesi, Artvin Çoruh Üniversitesi Orman Fakültesi Dergisi, 17(2): 158-162.

Barros L, Baptista P, Ferreira ICFR. 2007. Effect of Lactarius piperatus fruiting body maturity stage on antioxidant activity measured by several biochemical assays, Food Chem. Toxicol., 45: 1731-1737.

Benzie IFF, Strain JJ. 1996. The ferric reducing ability of plasma (FRAP) as a measure of "antioxidant power": The FRAP assay, Anal. Biochem., 239: 70-76.

Benzie IFF, Szeto YT. 1999. Total antioxidant capacity of teas by the ferric reducing / antioxidant power assay, J. Agric. Food Chem., 47: 633-636.

Bozdoğan A, Eker T, Bozok F, Ulukanlı Z, Doğan HH, Büyükalaca S. 2016. Multiple antioxidant and bioherbicidal assays of the edible mushroom species "Ramaria flava" in the Amanos mountains, Biointerface Res. Appl. Chem., 6(6): 1681-1685.

Bozok F, Eker T, Sezer G, Bozdoğan A, Doğan HH, Büyüklaca S. 2016. Investigation of antioxidant potential and phytotoxic effects of Ganoderma lucidum methanol extract, Turjaf, 4(3): 163-170.

Brand-Williams W, Cuvelier ME, Berset C. 1995. Use of a free radical method to evaluate antioxidant activity, Food Sci. Technol. Int., 28(1): 25-30.

Chan MMY, Fong D, Ho CT, Huang HI. 1997. Inhibition of inducible nitric oxide synthase gene expression and enzyme activity by epigallocatechin gallate, a natural product from green tea, Biochem. Pharmacol, 54: 1281-1286.

Doğan HH, Akata I. 2011. Ecological features of Tricholoma anatolicum in Turkey, Afr. J. Biotechnol, 10(59): 12626-12668.

Doğan HH, Şanda MA, Akata I. 2012. Mn, Fe, K, Na, and P contents in some Tricholoma (Fr.) Staude (Tricholomataceae) taxa from central Anatolia, Turkey, Fresen Environ Bull, 21: 3389-3393.

Elmastas M, Iş1ldak O, Türkekul I, Temur N. 2007. Determination of antioxidant activity and antioxidant compounds in wild edible mushrooms, J. Food Compos. Anal, 20: 337-345.

Garratt DC. 1964. The quantitative analysis of drugs (Vol. 3), Chapman and Hall Ltd, Japan. 
Gürsoy N, Sarıürkçü C, Cengiz M, Solak MH. 2009. Antioxidant activities, metal contents, total phenolics and flavonoids of seven Morchella species. Food Chem. Toxicol, 47: 2381-2388.

Halliwell B, Gutteridge JHMC. 1984. Oxygen toxicity, oxygen radicals, transition metals and disease, J. Biochem, 219: 114.

Halliwell B. 1996. Antioxidants in human health and disease, Annu. Rev. Nutr, 16: 33-50.

Kalmış E, Yıldız H, Ergönül B, Kalyoncu F, Solak MH. 2011. Chemical composition and nutritional value of a wild edible ectomycorrhizal mushroom, Tricholoma anatolicum. Turk J Biol, 35: 627-633.

Moyer RA, Hummer KE, Finn CE, Frei B, Wrolstad RE. 2002. Anthocyanins, phenolics, and antioxidant capacity in diverse small fruits: Vaccinium, Rubus, and Ribes, J. Agric. Food Chem, 50: 519-525.

Nakayama T, Yamada M, Osawa T, Kawakiskhi S. 1993. Suppression of active oxygen-induced cytotoricity by flavonoids, Biochem. Pharmacol, 45: 265-267.

Oyaizu M. 1986. Studies on products of browning reactions: antioxidative activities of products of browning reaction prepared from glucosamine, Japanese Journal of Nutrition, 44: 307-315.

Özdemir Ö. 2014. Determination of anticancer and modulation effects of Terfezia boudieri Chatin, Fomes fomentarius (L.) FR., Phellinus igniarius (L.) QUÉL. and Tricholoma anatolicum H.H. Doğan \& Intini on breast cancer cells, MSc Thesis, Konya, Turkey.

Özkaya D. 2015. Hepatoprotective effects against $\mathrm{H}_{2} \mathrm{O}_{2}$-induced damage in HEPG2 cells of Tricholoma anatolicum H.H. Doğan \& Intini, MSc Thesis, Konya, Turkey.
Rice-Evans CC, Miller NJ, Paganpa G. 1997. Antioxidant properties of phenolic compounds, Trends Plant Sci, 2(4): 152-159.

Smolskaitè L, Venskutonis PR, Talou T. 2015. Comprehensive evaluation of antioxidant and antimicrobial properties of different mushroom species. LWT-Food Sci. Techn, 60(1): 462-471.

Stacewicz-Sapuntzakis M, Bowen PE, Hussain EA, DamayantiWood BI, Farnsworth NR. 2001. Chemical composition and potential health effects of prunes: a functional food?, Crit. Rev. Food Sci, 41(4): 251-286.

Taşkın H, Büyükalaca S. 2016. Minimally processed mushrooms. Food engineering series book series (FSES), Minimally Processed Refrigerated Fruits and Vegetables pp 433-468.

Visioli F, Borsani L, Galli C. 2000. Diet and prevention of coronary heart disease: The potential role of phytochemicals, Cardiovasc. Res, 47: 419-425.

Vriesman MF, Paquay JBG, Voss H. 1997. A method for measuring nitric oxide radical scavenging activity. Scavenging properties of sulfur-containing compounds, Pharm. World Sci, 19(6): 283-286.

Wettasinghe M, Shahidi F. 1999. Antioxidant and free radicalscavenging properties of ethanolic extracts of defatted borage (Borago officinalis L.) seeds. Food Chem, 67: 399414.

Wong CC, Li HB, Cheng KW, Chen F. 2006. A systematic survey of antioxidant activity of 30 Chinese medicinal plants using the ferric reducing antioxidant power assay, Food Chem, 97: 705-711.

Yang JH, Lin HC, Mau JL. 2002. Antioxidant properties of several commercial mushrooms, Food Chem, 77(2): 229235. 